mediastudies.press • Social Media \& the Self: An Open Reader

\title{
Beauty Filters Are \\ Changing the Way Young \\ Girls See Themselves
}

\section{Tate Ryan-Mosley}

Published on: Apr 02, 2021

License: Creative Commons Attribution 4.0 International License(CC-BY 4.0). 
VERONICA STARTED USING filters to edit pictures of herself on social media when she was 14 years old. She remembers everyone in her middle school being excited by the technology when it became available, and they had fun playing with it. "It was kind of a joke," she says. "People weren't trying to look good when they used the filters."

But her younger sister, Sophia, who was a fifth grader at the time, disagrees. "I definitely was-me and my friends definitely were," she says. "Twelve-year-old girls having access to something that makes you not look like you're 12? Like, that's the coolest thing ever. You feel so pretty."

When augmented-reality face filters first appeared on social media, they were a gimmick. They allowed users to play a kind of virtual dress-up: change your face to look like an animal, or suddenly grow a mustache, for example....

\section{continue reading}

\section{OUTBOUND LINK}

"Beauty Filters Are Changing the Way Young_Girls See Themselves" (Tate RyanMosley, MIT Technology Review, April 2, 2021)

METERED PAYWALL (3 free articles per month) 